\title{
Questions and Answers after Brodsky's Reading, 21 February 1978*
}

\section{$Q$ : Do you like reading the poems in English?}

$A$ : No, no, I don't think so, no. Well, I'm just doing that from time to time. Mostly for fun. In this case, for something other than fun. But mostly for fun.

Q: Can I ask you to reminisce a little about Akhmatova? What was she like?

$A$ : This is a cruel thing, to do. This is a big topic. She was well-known ... what can I say? Well, in short, let's say in two minutes . . . I don't know . . . well, she was awfully tall . . . (Laughter) . . I guess I'm 5'10" or something like that, and, by Russian standards, it's quite a bit. Well, anyway, I never had any pangs, any feelings, about my height except when I was walking with her because she was awfully tall. When you were looking at her you could kind of grasp the reason why, occasionally, Russia has been ruled by the empresses. She had, if you wish, an imperial look.

Mind that she was old-at that time she was seventy. She was extremely witty. One thing, I guess, everybody could learn from her is how to bear everything that befalls one. If not for some kind of Christian teaching, if not for all that Christian propaganda, the knowledge of her only will give you quite a bit of Christianity.

What else about her? We didn't talk much about poetry; well, we did, certainly ... . but we were mostly talking about something completely removed from that. She used to say that metaphysics and gossip are the only interesting things. (Laughter) In that she was quite in line with that French philosopher Cioran. What else about her? Well, it's impossible to do it in two minutes.

$Q$. Did she ever speak to you in a gossipy way, or even metaphysically to you about Mandelstam?

A: Certainly.

Q: Which way? (Laughter)

$A$ : Well, she used to say that Nadezhda, his wife, is the happiest of all Russian literary widows. (Laughter) Because lots of the awfully good people, writers and poets, got killed and the recognition came to many of them. In the case of Mandelstam it did, and it was a universal one. . . We were discussing lots of things . . . we were discussing the origins of his . . . development, so to speak, because there was a great deal of discussion about where it's from. Akhmatova held that this was mostly from Pushkin. What else? She was never trying to compare herself to him. She knew the size of the man, the size

${ }^{*}$ We thank Gail Hanlon for preparing this manuscript, from tape, and Mr. Brodsky for helping correct it.

4 
of the poet. She was awfully humble. She used to say that "in comparison with him and Tzvetayeva I am just a little cow. I am a cow," that's what she used to say.

Q: Who do you read in Russian? I don't know much Russian and was wondering where to start.

$A$ : Well, if you are talking about the Twentieth Century, I'll give you a list of poets. Akhmatova, Mandelstam, Tzvetayeva (and she is the greatest one, in my view. The greatest poet in the Twentieth Century was a woman.) I said Pasternak, no? Well, this is kind of obvious; also Klyuev, Khodasevich, Zabolotsky. That should occupy you for quite a while. In terms of prose it's a little bit harder because out of the Nineteenth Century an idea emerged that Russian literature is still just as great as it was in the Nineteenth Century, some kind of inertia. . . And, very often, the things called the desirable were taken for the real ... as when you try to impose all the lingo you usually apply to the great dead on to the living writers.

Andrey Platonov is the greatest of them. He is an awfully interesting man. It is kind of hard to translate him in English; on the other hand, he has been translated into English. When you are reading that, his work in English, you should sort of make an imaginary correlative. It's not what you're reading, really, it's kind of one-tenth of what's there. Because he was using syntax in a rather peculiar way. He will lead the sentence into some kind of logical deadend. Always. Consequently, in order to comprehend what he is saying, you have to sort of "back" from the dead-end and then to realize what brought you to that dead-end. And you realize that this is the grammar, the very grammar, of the Russian language itself. And if you sort of estrange yourself and look at the page of what he has written it looks like kind of a big supermarket with all the items turned inside-out. Not only that, because he was never doing that for the game's sake. This kind of variety was the result of philosophical madness, not of aesthetic madness, and that's a big distinction.

Well, and who else? Well, I wouldn't say that there were people parallel to Platonov. There is a big interval after him, in my view. Well, this is my hierarchy, after all. ... There are awfully nice writers ... but in my opinion, the best Russian prose in the Twentieth Century has been written precisely by the poets, Mandelstam and by Tzvetayeva, and a little journal entitled in English, The Safe Conduct, by Pasternak. Dr. Zhivago is something else . . . it's a kind of a book, yah? (Laughter) Well, he was one of the greatest poets, but it's awfully hard to talk about it because the level of the adoration of those people is such that you can't really talk in this fashion. On those heights there is no hierarchy.

$Q$ : Do the Russian people listen to and respect their poets more than other countries?

A: I wouldn't say so.

Q: What about the government? Why are they afraid? Or are they? 
A: Because when you have a centralized government it tries to oversee all walks of life, and, most of all, well, whatever has to do with the printed matter. Government itself has a language, or a lingo or jargon, in which it operates. A writer has to, in order to sell himself (if not really "sell" himself, but at least to the public, to make himself noticeable, etcetera), he should try to utter it in some different, differing idiom from that of the State, which immediately puts him into the category of suspect, yes?

And, it's more interesting than that. There is a great deal of humbug about censorship. There is a terrific, well, choking censorship, that's quite right. And yet it's "life-size," if you wish. Or, at least for the writer, it's often a profitable thing in a way. Because the censorship turns the entire nation into the readership; it creates a certain stylistic plateau, yah? (Laughter) On which, when you are trying to do something on your own, you immediately get very noticeable. Besides, censorship accelerates the metaphoric speech. The metaphorical structure, yes? Because, while we are not allowed to say "the tyrants," well, sometimes, when you are saying "that man" (Laughter) it gives some kind of boost, a metaphorical boost, if you wish.

Why are they afraid? Well, they are not afraid, they're just stupid. (Laughter) No, no. I can understand how laughable it is, but it's not a laughable matter because, well, the stupid people are awfully mean.

Q: What sort of proof was offered in the trial where they proved that you weren't a poet?

$A$ : It's the other way around, because in our courts you ought to prove that you are something or are not something. There is no presumption of innocence in Russian courts. Whatever they charge you with, it is you who should prove that you are not guilty. It is not they who should prove that you are guilty, that's the point, whatever it is, poet or not poet. And actually I couldn't prove that. Nor could they prove that I am not. (Laughter) And besides it was years ago. It was . . . fifteen years ago.

Q: Would you like to go back and live in Russia again?

A: I would love to. I would really love to. Now it's getting a little bit complicated because I am for five years already here. And I'm just a little bit scared that I've changed quite a bit . . . well, not scared . . . got, well, if you wish, corrupted or whatever. (Laughter)

I would go there on one condition. And I think I am in a position to make conditions, to make demands. The condition would be that all my work would have to be published. Then I would like to return there and live the same life as I did. If something like that happens . . . if I am going back . . . I would like to bring some kind of change within this business of poetry.

Q: Do you think that's possible?

A: I don't think so. At least I don't see it.

Q: How do you think being involved in an institution like the University of Michigan has changed you . . . while in Russia you weren't affiliated with any academy? 
A: No, I wasn't. No, when I said that I had changed I didn't mean exactly the University of Michigan. Nor did I have in mind America in particular. What I've been thinking about is about getting older, more demanding, so to speak. Less willing to compromise, perhaps, because, well, there is not that much left to compromise. No, the University didn't change me. For myself, I like to teach. And there are a couple of people in this audience who can testify that I'm not lying. (Laughter)

$Q$ : I've noticed, and found it very interesting, that you do not write only about Russia. You write about subjects that are around you now. Do you ever find yourself at a real loss for words in Russian to describe, say, particular plants or trees or particularly lovely things?

$A$ : Good question. Never. (Laughter)

I was scared a great deal that such a thing might happen. And this is the kind of scare which sits pretty tightly nearby. So far, such a thing has never occurred. It's kind of a mind-boggling thing when, for instance, you're looking for something that needs a rhyme, and then there is no rhyme, and then you think, "Am I forgetting the language, or is there no such rhyme for this word?" Then you think there is no point to get paranoid because you ought to stay sane. But then you ask yourself "What for?" if you are really forgetting the language . . ."What for?" . . . just to stay sane?

Well, it's good to think about that. Are you doing that in order to prove to yourself that you can still write, or are you really writing out of necessity? In other words, all those questions which a writer usually encounters in his practice are kind of a little bit blown up . . . getting sort of more ominous in size than before. There is something in this quarrel between madness and sanity, perhaps. Though one could do without it . . .

Q: What's your opinion of Solzhenitsyn and the legend which has been built around him?

$A$ : (Long pause) Well, let's put it this way. I'm awfully proud that I'm writing in the same language as he does. I think he's one of the greatest men ever ... one of the greatest and most courageous men who has ever lived in this century. I think he is an absolutely remarkable writer. As for legend . . . you shouldn't worry or care about legend, you should read the work. And what kind of legend? He has his biography ... and he has his words.

Is that enough or should I say something else? •

Q: Please go on.

$A$ : He has been reproached quite a bit by various critics, by various men of letters, for being a second-rate writer, or a bad writer. I don't think it's just ... because the people who are judging the work of literature are sort of building their judgment on the basis of systems of aesthetics which we inherited from the Nineteenth Century. What Solzhenitsyn is doing in literature cannot be judged by this aesthetic standard just as his subject-matter cannot be judged by our ethical standards. Because when the man is talking about the annihilation or liquidation of sixty million men, there is no room, 
in my opinion, left to talk about literature and whether it's a good type of literature or not. In his case, literature is absorbed in the story.

What I'm trying to say is this. Curiously enough, he is the writer, but he uses literature, and not in order to create a new aesthetics but for its ancient, original purpose: to tell the story. And, in doing that, he's unwittingly, in my opinion, expanding the framework of literature. From the beginning of his career, as far as we can trace it on the basis of his successive publications, you see quite an obvious erosion of the genres.

What we start with, historically, is a normal novella, One Day, yes? Then he goes to something bigger, Cancer Ward, yes? And then he went to something which is really neither a novel nor a chronicle but somewhere in between, The First Circle. And then we've got this Gulag which is, I think, a new kind of epic. It's a very dark epic, if you wish, but it's an epic.

I think that the Soviet rule has its Homer in the case of Solzhenitsyn. I don't know what else to say. And forget about legends, that is real crap . . . about every writer.

Q: Are you comfortable with the English translations of your work?

$A$ : Sometimes, yes. Sometimes, no. An acquaintance of mine, a Swedish poet, Tomas Tranströmer, who has been, in my view, real botched up by Robert Bly (Laughter), once said that your attitude toward a translator sort of goes through three stages. First you trust him, and he kills you. The second time you don't trust him and he kills you just the same. The third kind of attitude involves certain masochistic traits in you. (Laughter) You say "kill me, kill me, kill me. . . ." And he kills you. (Laughter) It's not my joke . . . it's a quiet Swedish joke. (Laughter)

$Q$ : I've understood that the way contemporary Russian poets deliver their own work, the sort of declamatory style, comes from Mayakovsky's delivery. Is there any truth to that? That there is a school of declamation? $A$ : No. Not much. Not much. Well, actually, I never heard any recordings of Mayakovsky, but if it's so, if his style is declamatory, it comes from something much further back in our history. The first literature which appeared in Russian was liturgical literature: the chants, the recitals . . qu'estce c'est? psaltines?

Q: Psalms?

A: Yes, psalms. So, they've been rendered in Russian in kind of rhythmical form. And, in the Russian equivalent of high school, although there is no real equivalent, the children are made to memorize lines and lines of poetry. Pages and pages. And, after that, they are compelled to deliver that with socalled expression. That is, if they deliver it they should underline by their intonation, by stress, whatever it is, their understanding of the text. OK? So, this comes in the schooling, the normal schooling.

I remember as a child knowing by heart lots of things, lots of Pushkin, lots of Eugene Onegin, lots of Griboyedov, and other people. And this is what sets forth or releases this mechanism of mnemonic devices. And, in a way, 
this fashion or manner of recital, whatever it is, is in its own way a direct consequence of that liturgical tradition. All the more so because, as Theodore Roethke once said, the writing of a poem starts, if I remember the quote correctly, a "psychological mechanism of prayer." So, here you are.

$Q$ : One of my Russian friends insists that no American, or even any nonRussian, can ever understand Russian poetry. What do you say to that?

$A$ : Nonsense. Nonsense. Although, one thing should be said, and this is a really nice way to end the talk. In the fourth book of his Histories Herodotus tells a story. It deals with Scythia, with Scythians, the tribe that lives up north of Thanais, which I believe is the present day Donez. And the name of the tribe is already suspicious for a Russian ear. It's called Budini, well anyway, it has to do with the verb "to be," "byt," "bydi," of which the future tense could have sounded "budini," anyway ... . forget all that. He describes them in very general terms. And they are living in that area for timber; they make boats and build their houses and temples out of wood. And he says, and I checked that line even in Greek because I was astonished, "And they are in total amazement towards their own language." "They are amazed by their own language, astonished by their own language." There you are. All right?

Applause 